\title{
Heavy Metal Contamination of Top Soil at the Vehicles Workshop in Keffi Town, Nasarawa State.
}

\author{
Abiola K. A. ${ }^{1}$, Medugu N. I. ${ }^{1}$, Kadafa A, A. ${ }^{1}$, Opaluwa O. D ${ }^{2}$ \\ ${ }^{I}$ Departmentof Geography, Nasasarawa State University, Keffi, Nigeria \\ ${ }^{2}$ Departmentof Chemistry, Nasasarawa State University, Keffi, Nigeria
}

\begin{abstract}
Heavy metal concentration in soils from mechanic workshop areas in Keffi town, were assessed using the topsoil in the vicinity of the study area. Samples were collected along the North-East and South West transects based on the residual pathway and the undulating surface of the area at a varying distance of 1000 meters from the workshop area. The results obtained showed that $\mathrm{Zn}$ had the highest concentration levels followed by $\mathrm{Cu}$ and then lead in transects of the study areas while other metals: Nickel, Chromium and Cadmium had low concentrations in the top soils of the study areas. However, non-parametric analyses of Kruskal Wallis also show the degree of concentration and relationship among the heavy metals at the study sites. Copper, Lead and Iron though are low in the top soil but are persistence in the study sites.
\end{abstract}

Keywords: Heavy metals, Concentration, Kruskal Wallis, Nickel, Cadmium, Chromium, Copper, Iron, Transect and atomic Absorption spectrophotometry

\section{Introduction}

Soil figure largely in the land landscape, particularly of urban areas, often they are made where grass and shrubs are required to enhance the soil scientist appearance of our towns and cities. Until very recently, soil scientists in the developing countries have been primarily concerned with soil as a basis for agriculture and food production. Classification system and research into physical and chemical properties of soils have been focused towards the requirements of farming and forestry and to a degree towards the understanding of natural ecosystem, the urban environment, in which the majority of the population lives and into contact with the soil have been almost totally neglected. Barret (1987) concludes that the physical environment of towns and cities are profoundly affected by almost every kind of human activity from deliberated acts of construction management or vandalism to accidental or incidental pollution. An appraisal of urban soils by Craul (1985) points out that soils in urban areas are frequently disturbed and subjected to mixing, filling and contamination with heavy metals, herbicides, pesticide residual, oil and chemical from motor engines and also heavy machines. Urban development in Nigeria coupled with the presence of industrial, heavy engines and motor mechanic activities with urban areas lead to vary degrees of soil contamination with one or more materials. The association of soil heavy metal levels with its content in blood levels has received considerable attention in recent times in the developing and developed countries (Onianwa and Fakayode, 2000), thus making the monitoring of heavy metal in soil very significant to environmental health researchers.

In many cases, the source of elevated heavy metals, like lead $(\mathrm{Pb})$ and Mercury in the blood havebeen traced to contamination from industrial smelter, battery industry and mechanic workshops (Faragoet al., 1999, Onianwa and Fakoyode, 2000). Despite the growing rate of development in many of the less-developed third world countries only little or no attention is paid to such environmental issues. This is evident in the nonavailability of adequate monitoring data of sites which are liable to contamination and poor land-use planning as a result of which polluting workshop and industries are sometimes sited too close to surface water (River) which the people normally used for domestic activities in the area. There is also the lack of will power and regulation to enforce environmental control where these are in existence.

The paper investigates the extent of contamination of the surrounding area of a Vehicles mechanic workshop along river Autau, in Keffi town,Keffi Local government Area of Nasarawa State. The sites are within residential and commercial area of the town, which may be of significant environmental health concern because of the well-established hazardous effect of heavy metals to the people residing around the area concerned (Mushaket al., 1989, ATSDR, 1993). The study examined the distribution of heavy metals $(\mathrm{Zn} \mathrm{Cu} \mathrm{Ni} \mathrm{Cr}, \mathrm{Cd}$, $\mathrm{Hg}$ and $\mathrm{Ur}$ ) in the top soil around the mechanic village and highlights the exposure risk arising from the prevailing concentrations.

\section{Materials \& Methods}

Study Area:- is bounded by latitude $8^{\circ} 5^{\prime}$ and $8^{\circ} 52^{\prime} \mathrm{N}$ and longitude $7^{\circ} 53^{\prime}$ and $7^{\circ} 57^{\prime} \mathrm{E}$ and share boundaries with Karu LGA to the North, North west, South, and Kokona LGA stand on the North Eastern border. The area is between $450-1000 \mathrm{~m}$ above mean sea level found within the guinea savannah area with six month of dry and 
Heavy Metal Contamination Of Top Soil At The Vehicles Workshop In Keffitown, Nasarawa State.

wet seasons. The mean monthly temperature in the area ranges between $20^{\circ} \mathrm{C}$ to $34^{\circ} \mathrm{C}$ with the hottest month being month of March and April (Ayoade 2004). The vegetation of the study area is characterized by grass, weeds, and shrubs. The most dominant grasses include Sorghum and species like PennisetumPurpureum and AzonopusCompresses to mention but a few.

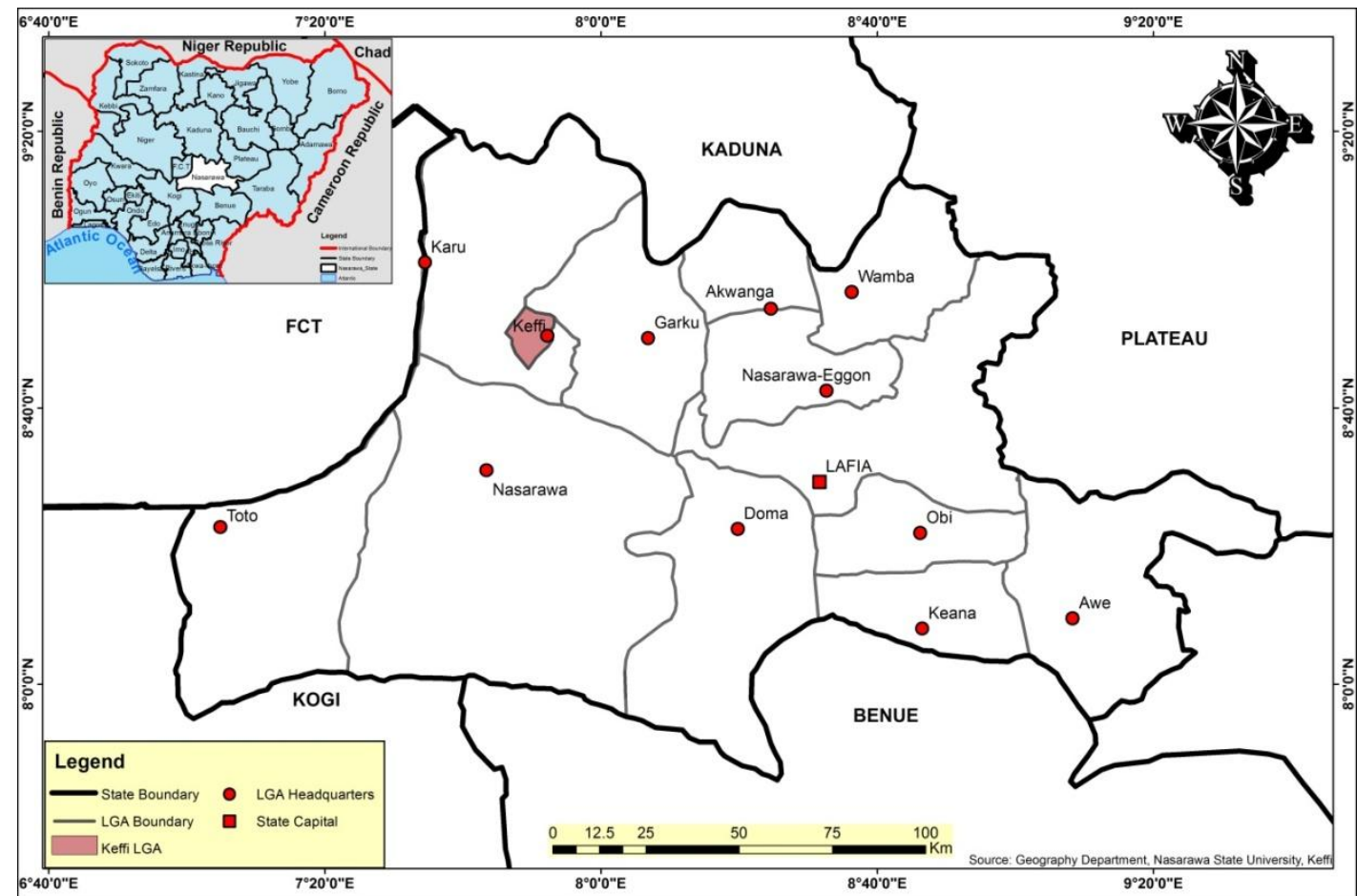

Fig: 1. Map of Nasarawa State Showing Keffi Local Government Area.

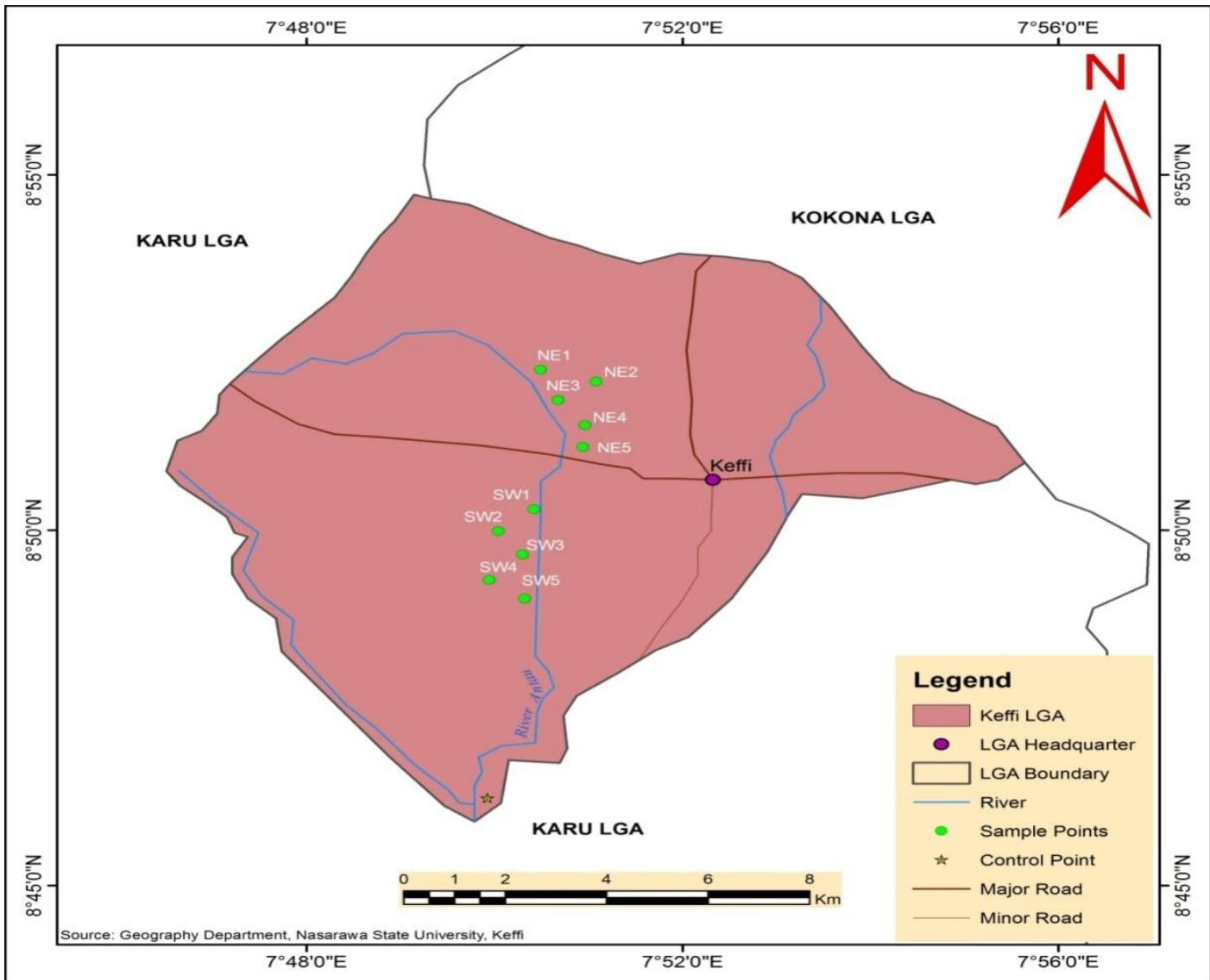

Fig: 2. Map of Keffi Local Government Area showing Sampling Site. 
Heavy Metal Contamination Of Top Soil At The Vehicles Workshop In Keffitown, Nasarawa State.

\section{Data Collection and Analysis}

The surrounding of the vehicles workshops were divided into two transects (Fig. 2) in the direction of North East and South West of the study area (Onianwa and Fakayode, 2000). Sampling points were chosen at varying distances from the mechanic area along each transect, as far as possible upto $1000 \mathrm{~m}$. Samples were obtained from the following point $0 \mathrm{~m} 250 \mathrm{~m} 500 \mathrm{~m} 750 \mathrm{~m}$ and $1000 \mathrm{~m}$. Residential housing and churches were located about 200 and 500m along the South-western parts of the transects and sample were obtained from open field at the church and Residential area. Control point samples for soil are obtained from locations in the town which were far remote from any major pollution sources around AgwanGanta, along old Nasarawa Road at the outskirt of the town which is about $10 \mathrm{~km}$ from the mechanic village.

Twenty sample sites were sampled around the vehicles workshops including the control site. At each of the sampling sites, four separate top soil samples were obtained by scooping the $0-10 \mathrm{~cm}$ top soil around the site with a soil auger. These were stored in polythene bags. Each of these four samples was separately analysed. Thus total of 40 soil samples were collected and analysed.

The soils were air dried in a clean room in the laboratory and then passed through a $150 \mu \mathrm{m}$ sieve (Onianwa and Fakayode 2000). Analysis was carried out by the method of Anderson (1976). 5g of dried soil was extracted with $50 \mathrm{ml}$ of $2 \mathrm{~m} \mathrm{HNO}_{3}$ in a covered glass bottle placed in a boiling water bath for $2 \mathrm{hrs}$. The filtered extract was then used for the metal analysis. Extract of the soil samples were analysed for the heavy metals, Copper Zinc Lead Nickel Chromium and Cadmium by flame atomic Absorption spectrophotometry (Perkin Eliner Model 2380). The instrument setting was described by Abiolaet al., 2010 and Aremuet al., 2008.

Table 1: Mean concentration $(\mathrm{mg} / \mathrm{kg}$ ) of heavy metals around the vehicles workshops Area

$\begin{array}{lllllllll}\text { TRANSECT } & \text { MATERIAL } & \text { DISTANCE } & \text { Cu } & \text { Zn } & \text { Ni } & \text { Pb } & \text { Cr } & \text { Cd } \\ \text { NE1 } & \text { SOIL } & 0 & 18.01 & 34.82 & 0.019 & 4.20 & 0.03 & 0.013 \\ \text { NE2 } & \text { SOIL } & 250 & 26.30 & 20.26 & 0.013 & 4.35 & 0.036 & 0.001 \\ \text { NE3 } & \text { SOIL } & 500 & 19.69 & 32.40 & 0.013 & 4.10 & 0.022 & 0.001 \\ \text { NE4 } & \text { SOIL } & 750 & 16.42 & 29.26 & 0.008 & 2.82 & 0.017 & 0.061 \\ \text { NE5 } & \text { SOIL } & 1000 & 10.13 & 17.60 & 0.001 & 1.11 & 0.001 & \text { ND } \\ \text { SW1 } & \text { SOIL } & 0 & 16.94 & 40.20 & 0.022 & 5.62 & 0.041 & 0.013 \\ \text { SW2 } & \text { SOIL } & 250 & 23.45 & 51.32 & 0.019 & 5.21 & 0.041 & 0.013 \\ \text { SW3 } & \text { SOIL } & 500 & 21.61 & 45.71 & 0.018 & 4.98 & 0.038 & 0.004 \\ \text { SW4 } & \text { SOIL } & 750 & 14.14 & 36.10 & 0.012 & 4.93 & 0.029 & 0.004 \\ \text { SW5 } & \text { SOIL } & 1000 & 09.63 & 92.20 & 0.007 & 2.32 & 0.014 & \text { ND } \\ \text { CTR } & \text { SOIL } & 10 \mathrm{KM} & 3.24 & 5.45 & \text { ND } & 0.024 & \text { ND } & \text { ND } \\ \text { WHO 2009 } & --- & - & \mathbf{3 . 0} & \mathbf{1 5} & \mathbf{0 . 1} & \mathbf{0 . 1} & \mathbf{0 . 5} & \mathbf{0 . 0 5}\end{array}$

Table 1 shows the average levels of heavy or trace metals in the soil at varying distances from the mechanic workshop soil as $\mathrm{Cu}$ levels fluctuates with the distance away from the mechanic workshop, at NE2 $(250 \mathrm{~m})$ the amount in $26.30 \mathrm{mg} \mid \mathrm{kg}$ more than the source which is due to the undulating surface of the landscape and the soil at that particular transect is a about $0.50 \mathrm{~cm}$ thicker than the rest of the transect however, at $\mathrm{NE}$ $(500 \mathrm{~m})$ the $\mathrm{Cu}$ is also increased more than the source but less than NE2 because the landscape is undulated(Onianwa and Fakayode, 2000).Subsequently other metals followed the pattern of $\mathrm{Cu}$ at the $\mathrm{NE}$ transect, of which the amount fluctuate between NE, NE2 and NE3, but decrease away from the mechanic workshop until it reaches $1000 \mathrm{~m}$. Meanwhile, control point which is about $10 \mathrm{~km}$ away from the vehicles workshop recorded very low amounts of heavy metals $\mathrm{Zn}$ was $5 ; 48 \mathrm{mg} \mid \mathrm{kg}$ followed by $\mathrm{Cu}(3.24)$, then $\mathrm{Pb}$ $(0.024)$ and the rest heavy metals $(\mathrm{Ni}, \mathrm{Cr}$, and $\mathrm{Cd})$ were not determined in the control soil. Generally, the steady decline in soil heavy metals was observed along the various transects. But levels in samples obtained from NE2 N3 and SW2 transects appeared to be relatively higher than along the others (Onianwa and Fakayode 2000).

The Kruskal-Wallis non parametric Analysis of variance on ranks $(\mathrm{P}<0.001)$ was used to confirm that differences observed in the heavy metal levels among the different transects and direction is statistically significant. The topography of the area is undulating with some direction higher ingredient than the others. However, the analysis of variance on Rank $(p<0.001)$ showed that the differences are significant, correlation between the heavy metals levels was very poor (Table 2).

Table 2:- Correlation coefficient $\mathrm{P}=0.005$ for heavy metals

\begin{tabular}{|l|l|l|l|l|l|l|}
\hline Metal & $\mathbf{C u}$ & $\mathbf{Z n}$ & $\mathbf{N i}$ & $\mathbf{P b}$ & $\mathbf{C r}$ & $\mathbf{C d}$ \\
\hline $\mathrm{Cu}$ & 1.00 & 0.412 & -0.248 & 0.318 & -0.195 & 0.342 \\
\hline $\mathrm{Zn}$ & 0.412 & 1.00 & -0.441 & 0.0716 & -0.496 & -0.521 \\
\hline $\mathrm{Ni}$ & -0.248 & -0.441 & 1.00 & 0.322 & 0.524 & 0.312 \\
\hline $\mathrm{Pb}$ & 0.318 & 0.0716 & 0.322 & 1.00 & 0.211 & 0.168 \\
\hline $\mathrm{Cr}$ & -0.195 & -0.496 & 0.524 & 0.211 & 1.00 & 0.218 \\
\hline $\mathrm{Cd}$ & -0.342 & -0.521 & 0.312 & 0.168 & 0.718 & 1.00 \\
\hline
\end{tabular}


The most significant positive correlations were obtained between $\mathrm{Cr}$ and $\mathrm{Cd}(0.718), \mathrm{Ni}$ and $\mathrm{Cr}(0.524)$ and $\mathrm{Ni}$ and $\mathrm{Pb}(0.322)$ the strongest association between $\mathrm{Cr}$ and $\mathrm{Cd}$ have shown in the work ofOnianwa and Fakayode (2000).

\section{Conclusion}

The relatively high concentrations of heavy metals found in soil in this study area, much as they represent pointers to possibly significant exposure risks and health implication of elevated heavy metals levels in the environment. The high concentrations obtained from this study underline the need for further studies, which should involve a detailed assessment of trace metals in the blood of the people living in the resident close to the vehicles workshop sites. It is also calls for an examination of waste management practices of the area in terms of disposition of scrap metals, cans and other motor and vehicle wastes.

\section{References}

[1]. Abiola K. A.,Medugu N. I., Ekanade, O., Opaluwa, O.D. and Omale, Muhammed A. B., (2014). Baseline concentration of Morbid leachate in well water sample of Enjema - Ofugo area in Ankpa town, Kogi State. Nigeria. International Journal of Innovative Sciences Engineering and Technology.Vol1., Issue 9. Pp175 - 188.www.ijiset.com

[2]. Abiola K. A.,Funmilola A.Medugu N. I., andAyuba H. K.,, (2014). Variability of Brine water quality in Keana and Awe, Nasarawa State, Nigeria.Unique Journal of Engineering and Advanced Sciences.,Vol 2., Issue 4 Pp36 - 45. www.ujconline.net

[3]. Abua, I., (1996) environmental impact of two waste dumpsite in Ibadan and Lagos on groundwater quality. Ph.D Thesis University of Ibadan (unpublished).

[4]. Abimbola A. F., Akdang, J.A. Akande, S.O. Olatunji, A.S. (2002). Environmental Impact Assessment of heavy metals associated with $\mathrm{Pb}-\mathrm{Zn}$ mineralization in Abakaliki Area southeastern Nigeria. In IAGOD Symposium and Geocongress 2002.Publishedby the geological survey of Namibia.

[5]. Agency for Toxic Substance and Disease Registry (ATSDR). 1993. Toxicology Profile for Lead. US department for Health and Human Services Atlanta, Georgia.

[6]. American Public Health Association (APHA) 2005.Standard Methods for the Examinationof Water and Wastewater.(21st Ed). Washington, D. C., Pp. 1368.

[7]. Andersson, A. 1976. On the determination of Ecologically significant fraction of heavy metals in soil. Swedish Journal of Agricultural Research 6, $19-25$.

[8]. Aremu, M.O., Majabi G.O. Nghargbu, K., Abiola, K.A. Ogah T. A and Magaji I.J. (2011). Baseline concentration of metals in water samples from streams, well and borehole within Okene Local Government Area, Kogi State, Nigeria. International Journal of Chemical Sciences. No 4; Vol. 2.

[9]. Aremu, M. O., Atolaiye, B. O.; Shagye, D.; Mounmouni, A. 2007. Determination of Trace Metals in Tilapia Zilli and ClariasLazera Fishes Associated with water and soil sediment from River Nasarawa in Nasarawa State, Nigeria. Indian , J . Multi. Res., 3(1): 159-168.

[10]. Ayoade, J. O. (2004). Introduction to climatology for the Tropics. Spectrum Books Limited. Ibadan, Nigeria (2 $2^{\text {nd }}$ Edition).

[11]. Onianwa P. C. and Fakayode S. O. 2000.Lead Contamination of Topsoil and Vegetation in the Vicinity of Battery Factory.Journal of Environmental Geochemistry and Health 22. $211-218$.

[12]. Osborne, L. L. and Wiley, M. J. (1998) Empirical relationships between land use/cover and stream water quality in an agricultural watershed. Journal of environmental management 26:9-27.

[13]. Pickering, Q. H. and Henderson, C. (1974).Industrial waste and its environmental impqcts. John Wiley and Sons Inc. 410pp

[14]. Prasanna, K. Y. (2001). A review of persistent organic pollutants Butterwork publishing Coy. Netherlands 220pp.

[15]. World Health Organization (WHO) 2009.Global Water Supply and SanitationAssessment. WHO Press, Switzerland, 1: 2-10. $11 / 29 / 2013$ 